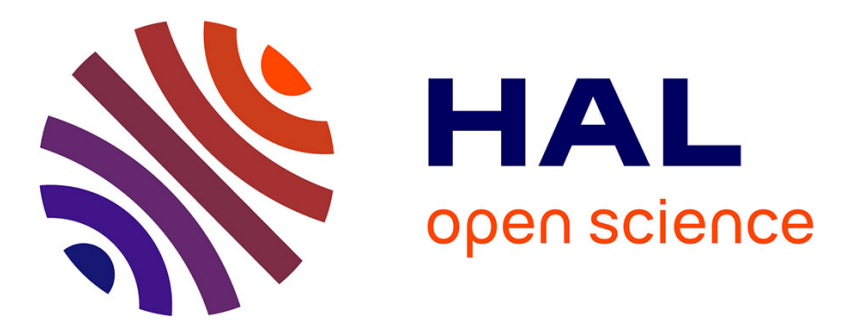

\title{
Relationship between the gross efficiency and muscular skin temperature of lower limb in cycling: a preliminary study
}

\author{
W. Bertucci, A. Arfaoui, L. Janson, G. Polidori
}

\section{To cite this version:}

W. Bertucci, A. Arfaoui, L. Janson, G. Polidori. Relationship between the gross efficiency and muscular skin temperature of lower limb in cycling: a preliminary study. Computer Methods in Biomechanics and Biomedical Engineering, 2013, 16 (sup1), pp.114-115. 10.1080/10255842.2013.815902 . hal-02310730

\section{HAL Id: hal-02310730 \\ https://hal.univ-reims.fr/hal-02310730}

Submitted on 11 Oct 2019

HAL is a multi-disciplinary open access archive for the deposit and dissemination of scientific research documents, whether they are published or not. The documents may come from teaching and research institutions in France or abroad, or from public or private research centers.
L'archive ouverte pluridisciplinaire HAL, est destinée au dépôt et à la diffusion de documents scientifiques de niveau recherche, publiés ou non, émanant des établissements d'enseignement et de recherche français ou étrangers, des laboratoires publics ou privés. 


\title{
Relationship between the gross efficiency and muscular skin temperature of lower limb in cycling : a preliminary study
}

\author{
W. Bertucci $* \dagger$, A. Arfaoui $\dagger$, L. Janson $\hbar$, G. Polidori $\dagger$ \\ $\dagger$ Biomechanics Laboratory, GRESPI EA4694, Faculty of Sciences, 51687 Reims, France
}

$\$$ Regional Training Structure in triathlon, 1 rue Arago, 51100 Reims, France

Keywords: Cycling Biomechanics; IR Thermography; Thermoregulation Process; Gross Efficiency

\section{Introduction}

In cycling the gross efficiency (GE, \%), defined as the ratio of the power output to the metabolic power (total energy expended according to the time) is one of the main determinants of the performance (Ettawa et al., 2009; Jobson et al., 2012). In the literature, the average GE values reported are varying from 10 to $25 \%$ (Faria et al., 2005). In this range, close to $75-90 \%$ of metabolic energy is not converted in mechanical energy but is used to maintain metabolic equilibrium (from the adenosine triphosphate hydrolysis) and released as heat. In the goal to maintain the central temperature close to $37.5{ }^{\circ} \mathrm{C}$, this produced energy must be dissipated using a thermoregulation process. Infrared thermography measurements can be used to analyze this thermoregulation process and understand the way one part of the energy dissipates (Arfaoui et al., 2012). The aim of this study is to analyze the relationships that may exist between the GE and the muscular skin temperature of lower limb in cycling.

\section{Methods}

Two male competitive cyclists (from regional to national level) with similar anthropometric characteristics (age: 16 years old, height: $1.79 \mathrm{~m}$, body mass: $63 \mathrm{~kg}$, body fat: $10.4 \%$ ) volunteered as subjects for this study. Prior to testing and after having received full explanation concerning the nature and purpose of the study, the subjects gave written informed consent. The study was approved by the ethics committee of the local institute.

The personal cyclist bicycle was fitted on the Fortius Virtual Reality cycle trainer (Tacx, Assenar, Netherlands). This ergometer is a stationary powermeter previoulsly validated (Peiffer and B Losco 2011; Bertucci 2012) which can be used in the laboratory conditions. The unit consists of a brushless motor attached to a drum which, when it is in contact with the rear tyre of an individual' $\mathrm{s}$ bicycle, creates resistance by acting as a generator / dynamo converting power to alternating current. In this condition, the incremental test was performed of a $4 \mathrm{~min}$ baseline at $100 \mathrm{~W}$, after which, the power output was increased by 40 W every 4 minutes until voluntary exhaustion.

During the tests the cardio-respiratory variables

$\dot{\mathrm{V}}_{\mathrm{O}_{2}}$ and carbon dioxide output $\dot{\mathrm{V}}_{\mathrm{CO}_{2}},\left(\mathrm{~L} \cdot \mathrm{min}^{-1}\right)$ were measured with the breath-by-breath telemetric and portable gas analyser device (Oxycon Mobile, Jaeger, Wurzburg, Germany). The pneumotachograph and analysers of the Oxycon mobile were calibrated before each test session according to the manufacturer's specifications.

GE $(\%)$ was calculated for each cycling condition. GE was calculated from measures of metabolic power, $\quad \dot{\mathbf{V}}_{\mathrm{O} 2}\left(\mathrm{~L} \cdot \mathrm{min}^{-1}\right), \quad \dot{\mathbf{V}}_{\mathrm{CO} 2}\left(\mathrm{~L} \cdot \mathrm{min}^{-1}\right)$, and power output during steady state conditions of each trial. The metabolic power was determined as described in Faria et al., (2005) from Brouwer's equation.

GE (\%) was determined using the following equation:

$\mathrm{GE}=$ (power output / metabolic power $) \times 100$

GE was computed at submaximal intensity of 140 $\mathrm{W}$ in the goal to perform the GE computation from steady state of the physiological variables. (Faria et al., 2005).

In order to evaluate the relationship between the cycling efficiency and the skin temperature of lower limbs, IR thermography was performed using an IR camera (Cedip Titanium HD560M) sensitive to wavelengths from 3.5 to $5 \mu \mathrm{m} \pm 0.25 \mu \mathrm{m}$. IR thermograms (Fig. 1) of thighs surface were taken before, during and after the cycling laboratory protocol (Arfaoui et al., 2012).

\section{Results and Discussion}

The results concerning the maximal consumption of oxygen, maximal aerobic power and GE of cyclists $\mathrm{N} 1$ and N2 are presented in Table 1. One can observe that the GE values are found to be in the range given in the literature. Moreover the GE (\%) is found to be higher for cyclist N2 than for cyclist N1.

In Figure 2(a) is represented the average skin temperature in the thighs area versus time before, during and after exercise. One can observe that the cyclist N2 presents the highest temperature evolution 


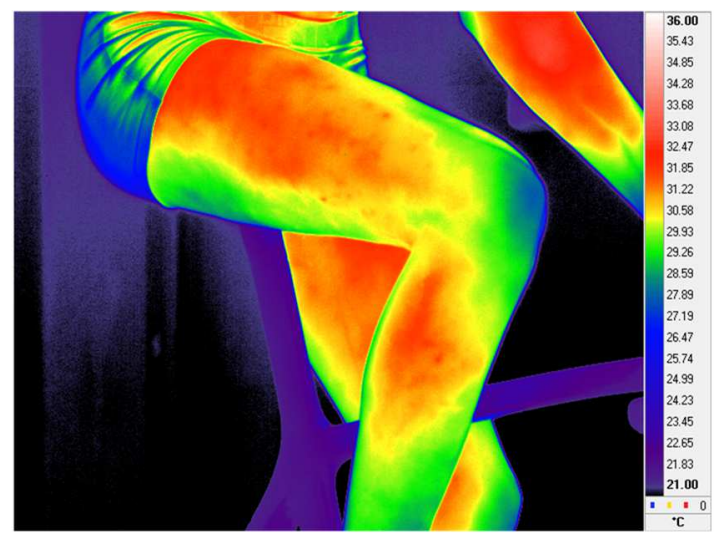

Figure 1: Infrared thermography of the lower limb

Table 1: Deduced physiological and biomechanics parameters

\begin{tabular}{cccc}
\hline & $\begin{array}{c}\text { Maximal } \\
\text { consumption } \\
\text { oxygen } \\
(\mathrm{mL} / \mathrm{min} / \mathrm{kg})\end{array}$ & $\begin{array}{c}\text { Maximal } \\
\text { aerobic } \\
\text { power } \\
(\mathrm{W})\end{array}$ & $\begin{array}{c}\mathrm{GE} \\
(\%)\end{array}$ \\
\hline $\begin{array}{c}\text { Cyclist } \\
\mathrm{N} 1\end{array}$ & 67.6 & 334 & 18.2 \\
\hline $\begin{array}{c}\text { Cyclist } \\
\mathrm{N} 2\end{array}$ & 55.5 & 339 & 23.6 \\
\hline
\end{tabular}

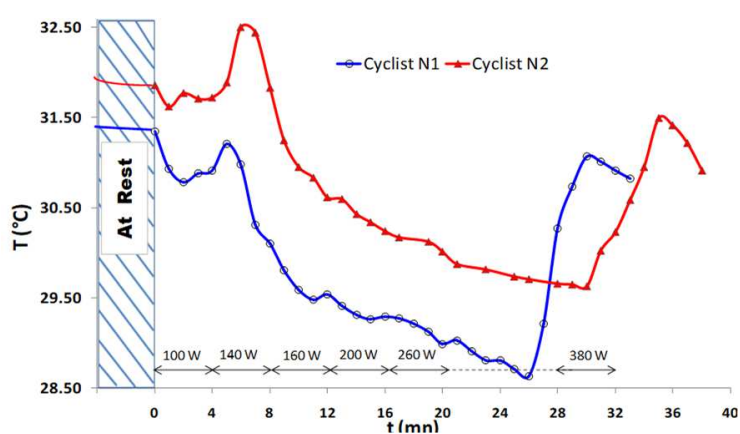

(a)

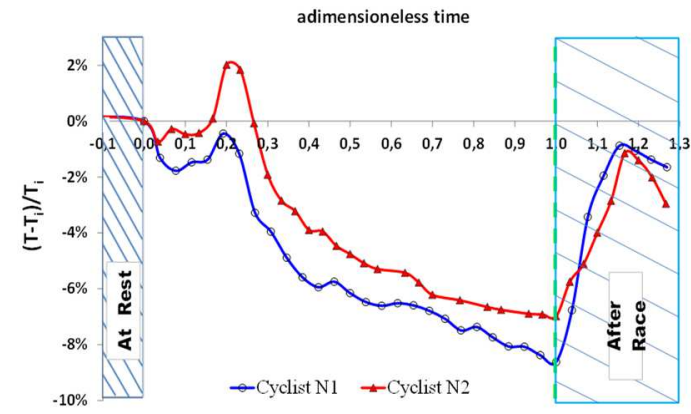

(b)

Figure 2(a): Skin temperature evolution (\%) of thighs versus time, Figure 2(b). Skin temperature rising of thighs versus adimensionless time.

At rest, the thighs skin temperatures are not equal. Indeed, for cyclist N1 thighs skin temperature is about $31.40^{\circ} \mathrm{C}$, it is about $31.9^{\circ} \mathrm{C}$ for cyclist $\mathrm{N} 2$. During race and after 5 minutes, the thighs skin temperature increases approximately $0.9{ }^{\circ} \mathrm{C}$ for cyclist N2. As the exercise is being conducted to ultimate fatigue, cyclists do not complete the exercise at the same time. It is the reason why in Fig $2 b$, results are presented according to skin temperature evolution (\%) and dimensionless time. Nevertheless, whatever the representation, one observes first a similar trend between the two curves, meaning a decrease in temperature with the exercise difficulty due to the thermoregulation process (Arfaoui et al., 2012). At the same power output the cyclist N1 with a GE of $18.2 \%$ produces much heat than the cyclist N2 with GE of $23.6 \%$. Our results suggest that the higher decreasing of skin temperature of the cyclist N1 is performed to increase the gradient between the central and the skin temperature in the goal to optimise the heat dissipation.

\section{Conclusions}

The main conclusions of this experimental study are that:

- A difference in the GE value leads to a difference in the skin temperature value,

- A lower GE value induces a higher decreasing $(\%)$ of skin temperature for lower limbs.

For a given cycling exercise, it seems that the IR thermography is a powerful tool to appreciate the efficiency level between cyclists.

This finding should be confirmed soon by a more statistical study including more subjects.

\section{Acknowledgments}

The authors would like to thank Mr Tschens, headmaster of the high school Arago in Reims (France), for having allowed us to perform experiments on its site.

\section{References}

Arfaoui A, Polidori G, Taïar R, Popa CV. 2012. Infrared thermography in sports activity, Chapter 7 in Infrared Thermography, Intech Ed:141-168.

Bertucci W. 2012 Analysis of the agreement between the Fortius cycling ergometer and the PowerTap powermeter PO during time trials of 6 and $30 \mathrm{~min}$. Comput Method Biomec and Biomed. Eng. 15:sup1, 212-214.

Ettama G. Loras H.W. 2009. Efficiency in cycling: a review. Eur J Appl Physiol 106:1-14.

Faria EW, Parker DL, Faria IE. 2005. The Science of Cycling Factors Affecting Performance Part 2. Sports Med. 35, 313-37.

Jobson SA, Hopker JG, Korff T, Passfield L. 2012. Gross efficiency and cycling performance: a brief review. J Sci Cycling Vol 1(1) 3-8.

Peiffer JJ, Losco B. 2011. Reliability/Validity of the fortius trainer. Int J Sports Med 32(5): 353-356. 